The pattern of disease caused by respiratory syncytial (RS) virus is distinctive. Severe lower respiratory tract infection, commonly bronchiolitis, is most prevalent among infants between 1 and 6 months of age. Primary infection outside of this age range is fairly common and well documented, but both neonates and children tend to handle the virus more successfully. One infection is insufficient to engender complete protection, but the severity of disease diminishes with successive infections as the child grows older. ${ }^{1}$

The search for an explanation of this unique epidemiological pattern has centred on the infant's immune response: effectively, all mothers will have encountered this ubiquitous virus and vulnerable infants passively acquire maternal immunity both transplacentally and, in some cases, through colostrum and breast milk. In addition, they are capable of mounting their own primary local and systemic responses. For babies who develop bronchiolitis the complex interaction of these passive and active defences results in an aggregate response insufficient to protect the lung from damage. Recent research has revealed several subtle defects, some age related and some RS virus specific, which together may begin to explain why patients with this virus fill our paediatric wards each winter.

\section{Transplacental antibody}

Babies acquire serum antibody passively from their mothers, and there is evidence that high maternal antibody concentrations may protect. ${ }^{2}$ The incidence of severe infection rises, however, from the second month of life when concentrations of maternal antibody in infant serum are still high. No satisfactory explanation for this phenomenon is yet available, but there are several ways in which maternally acquired antibody may be inadequate.

It has been suggested that protection of the infant lung against RS virus is mediated by antibody of the IgG3 subclass. IgG3 forms a minor component of the antibody acquired transplacentally, has a short half life, and declines to a nadir in infant serum at four to six weeks of life. ${ }^{3}$ Acute serum samples from infants infected with RS virus have been found to contain IgG3 anti-RS virus antibodies, albeit at low concentrations, but it might be argued that these have declined below a threshold necessary for protection. ${ }^{4}$ Alternatively, transplacentally acquired antibody may lack specificity for the strain of virus infecting the infant. RS virus is not monotypic and at least two subtypes have been described that have co-circulated during recent years. ${ }^{5}$ Studies in animals indicate that cross protection does occur but does not correlate with neutralising antibody concentrations and may depend on cross reactive cell mediated immunity, which does not cross the placenta. ${ }^{6}$

To protect the infant, antibody present in the blood must gain access to the site of infection. Enhanced transudation of serum immunoglobulin on to the mucosa occurs during the early inflammatory response to virus. Exposure of human macrophages to RS virus, but not influenza virus, stimulates production of an interleukin 1 inhibitor, which in vivo may delay inflammatory changes at the site of infection and thus hinder mobilisation of serum antibody. ${ }^{7}$

\section{Bronchiolitis and breast feeding}

Immunity to RS virus may also be acquired passively from the mother through breast milk, and breast feeding reduces the risk of lower respiratory tract disease. ${ }^{8}$ Colostrum and milk contain large amounts of $\operatorname{IgA}$ antibody, some of which is RS virus specific, and breast fed but not bottle fed neonates have IgA in their nasal secretions, which is probably passively acquired. Lower concentrations of anti-RS virus IgG antibodies are also found in milk and RS virus reactive $\mathrm{T}$ lymphocytes are present in the colostrum of up to $40 \%$ of mothers. Mothers of infants with severe RS virus bronchiolitis were no more likely, however, to have low anti-viral IgA or IgG antibody concentrations or lymphocyte reactivity in their colostrum and milk than mothers of infants with mild disease or infants of similar age with no evidence of infection. ${ }^{9}$ Animal studies have indicated that breast feeding may accelerate the matura- 
tion of the infant mucosal immune response, but in human infants we have found that nasal antibody responses in breast and formula fed infants with RS virus infection were similar both in timing and concentration. The mechanism of protection afforded by breast feeding thus remains obscure.

\section{The infant's systemic immune response}

Detailed recent comparisons of serum antibody responses of infants and older children have shown no significant qualitative differences in either immunoglobulin subclass or antigenic specificity. ${ }^{10} 11$ After primary infection with RS virus, however, serum antibody responses of infants are less efficient than those of older children. Some fail to respond at all and the low level and inconsistency of their systemic response probably contributes to their vulnerability to the virus. ${ }^{10}$ The poor serum antibody response of infants may, at least in part, result from an immunosuppressive effect of transplacentally acquired maternal antibody. ${ }^{12}$

Cell mediated immune responses are likely to be of considerable importance in recovery from infection as suggested by the severity of infection in patients with congenital $\mathrm{T}$ cell defects and by studies of cytotoxic $\mathrm{T}$ lymphocytes in animal models. ${ }^{13}$ Unfortunately, ethical and technical difficulties in the collection of blood samples from infants have restricted the range of investigations and further studies of human infants are required to assess their ability to mount a cytotoxic $\mathrm{T}$ cell response and assess its relevance to the pathogenesis of infection.

\section{Local responses in the respiratory tract}

While it is clear that high concentrations of nasal antibody protect adult volunteers against RS virus infection ${ }^{14}$ and stopping of virus shedding in the nasal secretions of infants coincides with the appearance of sIgA antibodies, ${ }^{15}$ the effect of local immune responses on the pathogenesis of virus infection of the lung has not been established. Measurement of nasal responses may have little relevance to lower respiratory tract infection and we have failed to detect any discernible relation between concentrations of nasal virus and severity of chest infection in RS virus infected infants (unpublished results). Nasal secretions are, however, accessible and may give a picture of the general level of immunoresponsiveness in the infant.

Local, like systemic, responses are sluggish in the very young. This poverty of response may be particularly dangerous as nasal interferon ${ }^{16}$ and IgM antibody responses in RS virus infected infants are considerably lower than those in infants of the same age infected with other respiratory viruses (unpublished results). Suppressed local responses may reflect the immunosuppressive abilities of RS virus described by Domurat ${ }^{17}$.

Although these subtle defects may render young infants particularly vulnerable to RS virus infection, other factors seem to determine the outcome of individual infections, as neither nasal interferon nor secretory antibody responses correlate with disease severity (unpublished results). Welliver et al, however, report an association between early and high nasal anti-RS virus IgE antibody secretion and lower respiratory tract disease. ${ }^{18}$ They have postulated that bronchiolitis results when a suppressor cell defect in RS virus infected infants leads to uncontrolled local IgE synthesis, degranulation of mast cells, and bronchoconstriction. Unfortunately, antigen specific IgE assays have proved difficult to establish elsewhere and these exciting results have not been confirmed in other laboratories.

\section{References}

1 Glezen WP, Taber LH, Frank AL, Kasel JA. Risk of primary infection and reinfection with respiratory syncytial virus. $A m J$ Dis Child 1986;140:543.

2 Ogilvie MM, Vathenen AS, Radford M, Codd J, Key S. Maternal antibody and respiratory syncytial virus infection in infancy. $J$ Med Virol 1981;7:263.

${ }^{3}$ Hornsleth A, Bech-Thomsen N, Friis B. Detection of RS-virus IgG-subclass-specific antibodies: variation according to age in infants and small children and diagnostic value in RS-virus infected small infants. $J$ Med Virol 1985;16:321-8.

${ }^{4}$ Watt PJ, Zardis M, Lambden PR. Age related IgG subclass response to respiratory syncytial virus fusion protein in infected infants. Clin Exp Immunol 1986;64:503.

5 Hendry RM, Tallis AL, Godfrey E, Anderson LJ, Fernie BF, McIntosh K. Concurrent circulation of antigenically distinct strains of respiratory syncytial virus during community outbreaks. J Infect Dis 1986;153:291.

- Prince GA, Horswood RL, Koenig DW, Chanock RM. Antigenic analysis of a putative new strain of respiratory syncytial virus. $J$ Infect Dis 1985;151:634-7.

7 Roberts NJ, Prill AH, Mann TN. Interleukin 1 and interleukin 1 inhibitor production by human macrophages exposed to influenza virus or respiratory syncytial virus. J Exp Med 1986;163: 511.

${ }^{8}$ Pullan CR, Toms GL, Martin AJ, Gardner PS, Webb JKG, Appleton DR. Breast-feeding and respiratory syncytial virus infection. $\mathrm{Br}$ Med $J$ 1980;281:1034-6.

9 Nandapalan N, Taylor C, Scott R, Toms GL. Mammary immunity in mothers of infants with respiratory syncytial virus infection. J Med Virol 1987. (In press).

10 Murphy BR, Graham BS, Prince GA, et al. Serum and nasalwash immunoglobulin $G$ and $A$ antibody response of infants and children to respiratory syncytial virus infection. J Clin Microbiol 1986;23:1009-14.

1 Wagner DK, Graham BS, Wright PF, et al. Serum immunoglobulin $\mathrm{G}$ antibody subclass responses to respiratory syncytial virus $F$ and $G$ glycoproteins after primary infection. $J$ Clin Microbiol 1986;24:304-6.

12 Hemming VG, Prince GA, Horswood RL. Studies of passive immunotherapy for infections of respiratory syncytial virus in the respiratory tract of a primate model. $J$ Infect Dis 1986;152:1083. 


\section{Toms and Scott}

${ }^{13}$ Bangham CR, Cannon MJ, Karzon DT, Askonas BA. Cytotoxic $T$-cell response to respiratory syncytial virus in mice. $J$ Virol 1985;56:55-9.

14 Mills J, Van Kirk JE, Wright PF, et al. Experimental respiratory syncytial virus infection of adults. Possible mechanisms of resistance to infection and illness. J Immunol 1971;107:123-30.

15 McIntosh K, McQuillin J, Gardner PS. Cell-free and cell-bound antibody in nasal secretions from infants with respiratory syncytial virus infection. Infect Immun 1979;23:276-81.

${ }^{16}$ McIntosh K. Interferon in nasal secretions from patients with viral respiratory tract infections. J Pediatr 1978;93:33-6.
${ }^{17}$ Domurat F, Roberts NJ, Walsh EE, Dagan R. Respiratory syncytial virus infection of human mononuclear leukocytes in vitro and in vivo. $J$ Infect Dis 1985;152:895.

${ }^{18}$ Welliver RC, Kaul TN, Sun M, Ogra PL. Defective regulation of immune responses in respiratory syncytial virus infection. J Immunol 1984;133:1925-30.

$\mathrm{G} \mathrm{L}$ Toms and $\mathrm{R}$ ScotT Department of Virology, University of Newcastle upon Tyne, Newcastle upon Tyne NE2 $4 \mathrm{HH}$ 